\title{
b̊crhconf
}

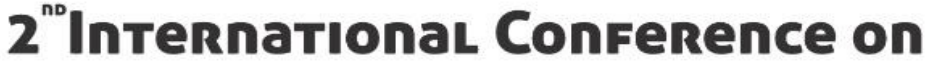 \\ RESEARCH IN HUMANITIES}

22 - 24 November, 2019 - Paris, France

\section{Development and Perspectives of Georgian Military Terminology on the Basis of its Etymological Analysis and under the Influence of Historical and Political Changes in the Country}

\author{
Tamar Gogokhia
}

Georgia. Ph.D. student at the faculty of Translation and Intercultural Relations at Ivane Javakhishvili Tbilisi State University. Translator and interpreter at the Ministry of Defence of Georgia

Georgian military terminology has reached a culmination of its development by now. Different historical and political factors have had an influence on this process. The basic issue is that the main base of Georgian military terminology was created in Soviet times; but after dismantlement of the Soviet Union and liberation of the country, Georgia's political course has changed drastically. The country has developed close political and military relationship with several European countries and the United States of America with this being followed by changes in its military structure. This has resulted in the necessity of establishment of new Georgian military terminology on the basis of the U.S. military term base. The process of term-establishment has almost been simultaneous to the publication of doctrines. The differences in semantic and syntactic structure of English and Georgian languages have made the process even more toilsome. As laborconsuming as it is, studying the etymology of the English term is also essential to yield flawless results.

Key words: Military terminology, term-establishment, doctrine, political, perspectives

\section{Introduction}

The article entitled Development and perspectives of Georgian military terminology on the basis of its etymological analysis and under the influence of historical and political changes in the country aims to cover historical and political background of the country in XX-XXI centuries having an influence on the development of overall military system and mostly terminology in Georgia, to make an overview of the problems of military translation in general and continue with more specific issues of translating USA and NATO military texts into Georgian. 


\section{ל̊crhconf}

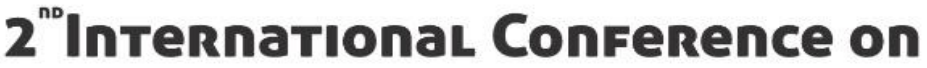 \\ RESEARCH IN HUMANITIES}

\section{2 - 24 November, 2019 - Paris, France}

In the given article we have used quantitative method of research and case study. We have studied technical and field manuals and the etymology of specific military terms to follow the steps of its development and to provide Georgian military translators with some useful guidelines.

With military translation the problem is bifold. Translators should have extensive military knowledge and should be well aware of the military system and hierarchical structure of both their country and the country of their source language. Besides, they should keep pace with emerging technological changes and work on the development of relevant terminology.

Military terminology is unique in one more way. It is abound with abbreviations, acronyms and idioms. For instance, NATO texts are characterized by overwhelming use of abbreviations which have specific NATO-related meaning and can confuse even an experienced translator.

Furthermore, military translation is simply a matter of life and death. Mistranslation of some specific term or abbreviation might lead to fatal results: misuse of some weapon system, new technology and even undermining of entire tactic or strategy. So, the sense of responsibility is of extreme importance for military translator.

\section{Body of paper}

\subsection{Historical background}

XX and XXI centuries have been greatly significant in historical, political and military viewpoints. Two World Wars took place in the twentieth century. Besides, this period has been marked as a period of technological progress. Therefore, military terminology is changing and developing because of emergence of new weapons systems, equipment and technology, new structure of military force, and tactics and strategies changed.

Political situation in Georgia has been drastic during this period. It has been a period of fundamental changes. A new state has been formed with developing military system and the process still continues. This had great influence on the development of military terminology in the country and therefore, a short overview of political and historical situation in Georgia of those days is given in the following several paragraphs. 


\title{
ל̊crhconF
}

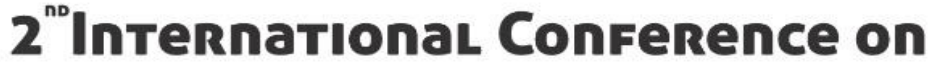 RESEARCH IN HUMANITIES}

\author{
22 - 24 November, 2019 - Paris, France
}

After the end of World War I and several revolutions in Russia, Georgia grabbed a chance and declared Independence in 1918. Russia was not content with the situation in Caucasus and made a special agreement with Georgia trying to win Georgian land once more. But Georgia had several attempts to evade Russian influence and they solicited political recognition from the West. The West, in the beginning, voted against Georgia's membership of the League of Nations. Only in January 1921, the Western policy reversed and Georgia was granted de jure recognition. President of the First Republic of Georgia, Noe Zhordania, received congratulations from Soviet Russian Officials too, who assured him that they wanted peace and friendship with Georgia. Though, the First Republic of Georgian did not last long. In 1921 Soviet Army entered the territory of Georgia accusing the country in fighting Russian soldiers, called the conflict a war between Georgia, Azerbaijan and Armenia and even offered to act as peace-maker. Simultaneously, the uprising against "forces of European reaction" started in Georgia. Georgian military system was not properly developed yet; the country did not even have a regular army. All they had was love of their land and people, which obviously was not enough in the fight against Russia. So, Georgia's resistance was fiery but on 25 February 1921 Russian Red Army, upon their fourth attempt, succeeded in occupying Tbilisi and Georgian Socialist Soviet Republic was proclaimed. This period lasted until 1991 - the end of Soviet Union. Under Soviet regime, Georgia did not have regular army and all weapon system and military technology was borrowed from the Soviet Union. Russian language was dominant in the whole country and in the military system too. Terminology was either pure Russian, or the borrowings.

Upon dismantlement of Soviet Union, on April 1991, Georgia proclaimed independence from Moscow once more. Though, Russia-Georgian relationships have been quite complicated since. Due to two invasions into the country, in 1992 and in 2008, Russia has occupied 20\% of Georgian land, its seaside - Abkhazeti and a part of Georgia situated near Russian border - Samachablo.

After declaration of independence on April 9, the country reconstituted or even founded its independent Armed Forces (Defence Forces - since 2019) on April 30, 1991. Nowadays, this date is celebrated annually all over the country as a Day of Georgian Armed Forces. By now, Georgian active army counts 37,000 personnel.

This period was distinguished by turbulences and diversity in political and social fields. The country was tearing apart between Europe and Asia, US and Russia, trying to liberate from chains and find its way. 


\title{
ל̊crhconF
}

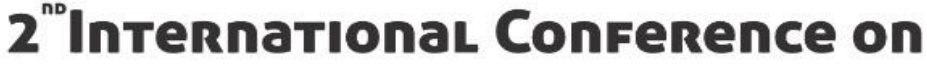 RESEARCH IN HUMANITIES}

\author{
22 - 24 November, 2019 - Paris, France
}

Upon the very start of XXI century, Georgia appeared to receive a new lease of life, when in 2003, the regime of the country was brought down due to so called "Rose Revolution" and new era started. This proved to be a period of greatly expanding relationships with Europe and USA. Georgia has widened its horizons and quickly received diplomatic recognition from many counties being accepted as a member of the United Nations and the Organization for Security and Cooperation in Europe. Thus Georgia began to appear on maps as European country.

Eventually, the country started to renew its weapon system and Russian Kalashnikov was replaced by American M4s, military technologies and tactics have been changed too adapting itself to those of the West. Georgian Armed Forces started to adapt themselves to US and NATO system which emphasized the need of translating those military doctrines and manuals followed by the NATO and the U.S. So, the need for highly qualified military translators has been increased.

The Georgian military system is undergoing changes and refinements. The Georgian Armed Forces participate in the peacekeeping missions in Iraq and Afghanistan and get experience, study how to work with U.S. and European equipment and military systems. Besides, Georgia purchases equipment from the West and soldiers need technical and tactical manuals to use them properly.

\subsection{Helpful Sources in the process of rendering a high quality military translation}

As long as the process of term-establishment still undergoes changes and even the key terms are not confirmed, the work to be done by translators is even harder. The absence of terminologist in the Doctrine Development Center (DDC) of the Ministry of Defence of Georgia makes things even more complicated. Translators have to work on the term-establishment simultaneously with the translation process. Each translator has his/her own glossary and those glossaries are merged at the end of the year. The translators use different methods to come up with the best Georgian equivalent of English term. In some cases they make etymological analysis of the word. The whole staff of the Doctrine Development Center (DDC), translators, masters of literary style and layout designers on the one hand and military subject-matter experts on the other, work on the production of proper translations of U.S. and NATO military doctrines and manuals. 


\section{כocrnconf}

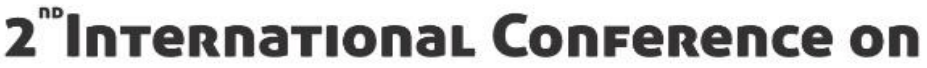 RESEARCH IN HUMANITIES}

\section{2 - 24 November, 2019 - Paris, France}

Though, there have been attempts to relieve this tremendous work. Georgian Defence Forces agreed upon a joint project with the Lexicographic Center of Ivane Javakhishvili Tbilisi State University. Due to consolidated hard work of both parties a military dictionary was developed. It is available on the website www.mil.dict.ge. (figure 2.1.) This dictionary is a product of hard work of Georgian prominent lexicographer Tinatin Margalitaze and her team of professionals on the one hand and the team of the officers and civilians from the Ministry of Defence of Georgia on the other. Although this dictionary is of great importance for every military translator, it covers only several fields of military system, namely artillery, fire support, maintenance, but some other fields, like communications and aviation are not covered due to limited budget of the project and changes in the command of the Ministry of Defence.

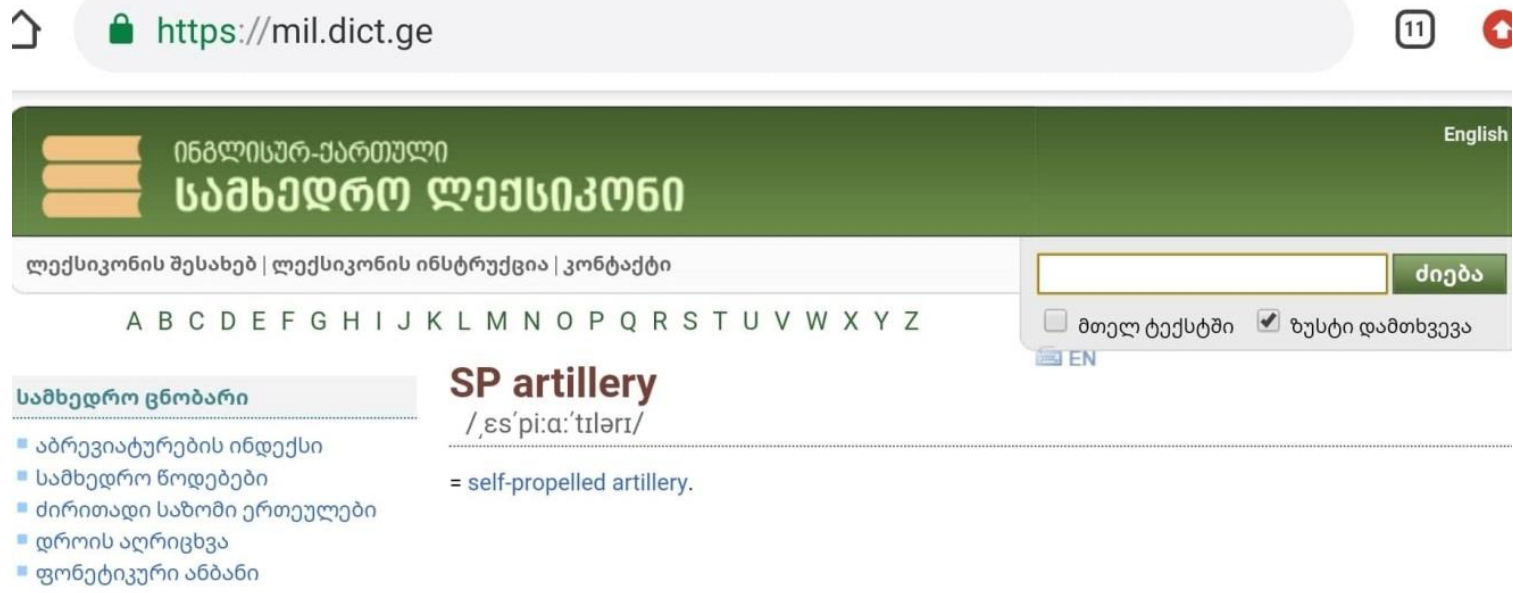

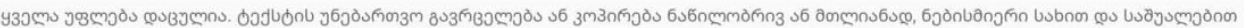
simducingonos.

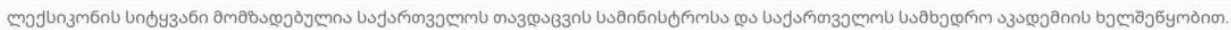

RTOPGE

0.0505

Figure 2.1. English-Georgian Military Dictionary

The other helpful source for translators of the Ministry of Defence is Field Manual (FM) 1-02. This manual covers military terminology of all distinctive military fields and it was translated even before the development of DDC. However, translated version of FM 1-02 had its own shortfalls. The original manual was created for the U.S. Army, not Georgian. Therefore, a lot had to be updated and adapted to the needs of Georgian Armed Forces. So, necessity to develop a group involving translators, masters of literary style and subject matter experts of different Military Occupational Specialties was emphasized. 


\section{כCrhconf}

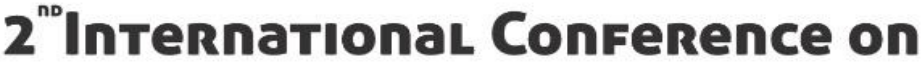 \\ RESEARCH IN HUMANITIES}

\section{2 - 24 November, 2019 - Paris, France}

This group was created in 2016 and due to their tremendous work the manual was updated and adapted to Georgian military system.

Nowadays, Soldiers and educational institutions of the Ministry of Defence of Georgia are trying to adopt this terminology and use it in their everyday life. Although, considering the fact that, owing to the Western-Georgian progressive relations, lots of Georgian soldiers attend courses and trainings in the U.S. and different European countries and study there in English. Therefore, they feel more comfortable using English terms than their Georgian equivalents. This also hinders the process of termestablishment.

\subsection{Translation Procedures}

When translating military texts, its specific features should be considered. Military texts are characterized by the following specifics:

a. long and winding sentences;

b. frequent use of abbreviations and acronyms;

c. redundancy, when several near synonyms are used in close sequence

Frequent use of abbreviations and acronyms makes long sentences even longer. Doctrine Development Center (DDC) of the Ministry of Defence of Georgia tried to resolve this problem by development of the list of corresponding Georgian abbreviations. Military subject matter experts and masters of literary style worked on this issue. Though, the project proved to be unsuccessful in a way. Georgian language has its own unique alphabet, one of the fourteen alphabets in the world. It has 33 letters and sounds some of which are pronounced quite awkwardly, especially some consonants and their pronunciation in sequence makes even more awkward sounds which is inconvenient and even funny to pronounce. Therefore, Georgian abbreviations could not change English ones in the texts.

Analyzing the specific characteristics of the text is only one step during the translation process. Trustworthy and high quality translation should go through several steps.

1. Before the start of translation process, the source text is carefully studied by the translator; 


\title{
b̊crhconf
}

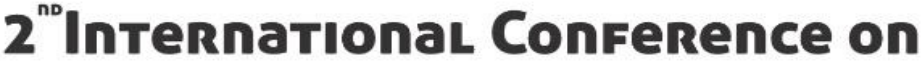 \\ RESEARCH IN HUMANITIES}

\author{
22 - 24 November, 2019 - Paris, France
}

2. Considering, that English is an analytic language and Georgian is synthetic, semantic and syntactic approximations of source and target texts are made;

3. As long as every manual has its own glossary of abbreviations and terms, this is the first part of the text that is handled by translator. Terms in the glossary are carefully translated and confirmed;

4. In case when different editions of the text exist, translator should contrast them with each other in order to be aware of changes made throughout the history of their existence.

5. After translation is completed, it is transferred to masters of literary style; they are Georgian language specialists and adapt the text to the standards of Georgian grammar, stylistics and syntax;

6. Next step is the transfer of the text to military subject matter experts who develop Georgian doctrines on the basis of those translations;

7. Finally, texts are handed to layout designers who prepare them for publishing and they are either uploaded to the online library of the MOD or published by the publishing house of the MOD.

\subsection{Example of Etymological Analysis of the Term}

As long as an etymological analysis is very comprehensive and requires lot of time and hard work, we will include the etymological study of one of the most important military terms in this article. This term we chose is "Army". The etymology shows that the root of the word is of a French origin. It has a long history which dates back to IndoEuropean languages: army $\rightarrow$ armed (force) $\rightarrow$ armee (Middle English) $\rightarrow$ armee (Anglo-Norman or Old French) $\rightarrow$ armāta ("armed force") (Latin of Middle Ages) $\rightarrow$ armäre ("to arm")(Latin). The etymological study falls to the word arma the stem of which leads us to first Indo-European word meaning Unify, Unity. This same term appears in Ancient Greek: ả $\rho \theta \mu$ ó (arthmós).

But etymological analysis alone will not result in a correct term in target language. Simultaneously, structural analysis of military systems of both countries and linguistic analysis of the word should be conducted. 


\section{b̊crhconf}

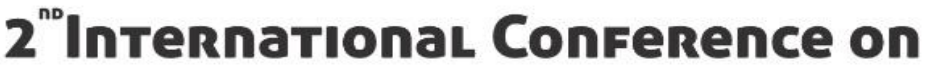 \\ RESEARCH IN HUMANITIES}

\section{2 - 24 November, 2019 - Paris, France}

In the U.S. military system word "Army" is used for a component with its own land, air and marine capabilities. It should be emphasized that U.S. Army has separate Land, Air, Maritime and Space domains each of them having land, air and marine capabilities. Therefore, due to humble resources, personnel, small territory and capabilities of Georgian Armed Forces, who do not have any wide domains similar to the U.S., Georgian equivalent of the word "Army" can be both 'SeiaraRebuli Zalebi (Armed Forces) and 'saxmeleTo jarebi (Land Forces/troops). Due to reforms made in the Ministry of Defence in 2019, Georgian Armed Forces (saqarTvelos SeiaraRebuli Zalebi) changed its title to Georgian Defence Forces (saqarTvelos Tavdacvis Zalebi). This complicates the situation even more. Which term to use? This is the question translators are tortured with most of the time using this specific term. Correct decision can be made only due to vast experience and knowledge of military structures of both countries. All the above said emphasizes the importance of highly qualified military translators and the sense of responsibility and accuracy they should have.

\section{Conclusion}

As a conclusion, we should emphasize that despite military translation requiring a high degree of accuracy, word-for-word translation is unacceptable because it leads to an awkward transmission of a message from the source text to the target text.

The author of this paper hopes that the article will make its moderate contribution to the advancement of the field of military translation and assist Georgian military translators, especially those who are new and less experienced in this field, to expand their knowledge and avoid further errors.

\section{REFERENCES:}

[1] Forsyth J. (2015) The Caucasus, History. $1^{\text {st }}$ ed. University Printing House, Cambridge, U.K.

[2] Department of the Army (2004) Operational terms and graphics, $2^{\text {nd }}$ ed., Createspace, U.S.

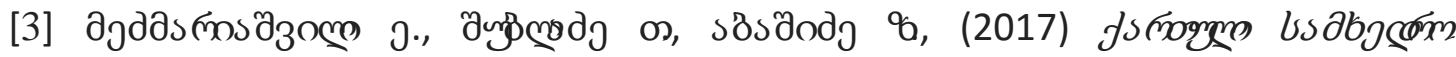

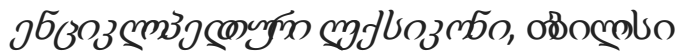

Medzmariashvili E., Shubladze T., Abashidze Z. (2017) Georgian military encyclopedic dictionary, Tbilisi 


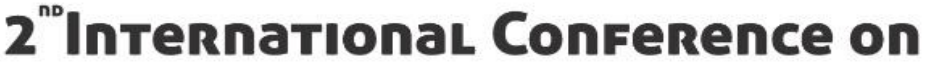 RESEARCH IN HUMANITIES}

\section{2 - 24 November, 2019 - Paris, France}

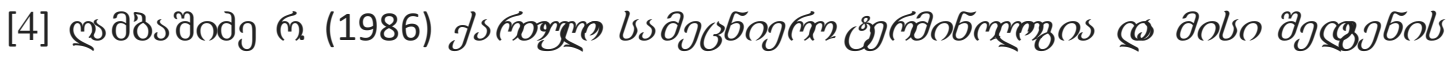

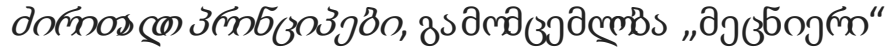

Ghambashidze R. (1986) Georgian scientific terminology and main principals of its establishment, Metsnieri

[5] English-Georgian Military Dictionary. Available: https://www.mil.dict.ge/

[6] Comprehensive English-Georgian Online Dictionary. Available: https://www.dictionary.ge/ 